Copyright (C) 2018 by Academic Publishing House Researcher

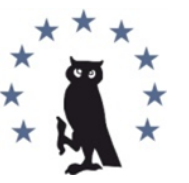

Published in the Russian Federation

European Researcher. Series A

Has been issued since 2010.

ISSN 2219-8229

E-ISSN 2224-0136

2018, 9(3): 235-248

DOI: 10.13187/er.2018.3.235

www.erjournal.ru

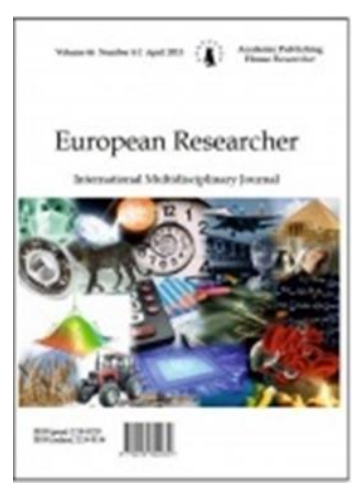

\title{
Organizational Commitment of Hospital Nurses: an Empirical Study on Work-Life Balance and Burnout Management
}

\author{
Honorata Ratnawati Dwi Putranti a, * \\ a University of Semarang, Indonesia
}

\begin{abstract}
This research aims to determine the correlation between work-life balance and burnout management toward nurse's organizational commitment and job satisfaction as intervening variable. The respondents of this research are female nurses in dr. R. Soeprapto Cepu Hospital which amounted to 113 people. All female nurses working there are the respondents. This research applies quantitative approach in which the hypothesis testing uses path analysis (SPSS 22), open questionnaire, and interview approaches. The in-depth interview approach aims to better understand the management and attitudes of individuals in dealing with the work-life balance and stress they experience. Stress management of the nurses can be divided into three types namely: stimulus/reactive, preventive/responsive, and transactional/common. The research findings found that the effect of work-life balance toward organizational commitment directly was positive and significant. The effect of burnout toward organizational commitment directly affected negatively. This research analyzed the results of open questionnaires, so as to understand the problems experienced by the nurses more deeply. In addition, it is expected to provide input for hospital institutions in taking policy to solve the stress problems experienced by hospital nurses.
\end{abstract}

Keywords: work-life balance, burnout, organizational commitment, job satisfaction.

\section{Introduction}

Hospital nurses are the dominant human resources involved in providing hospital services. According to the data (Ministry of Health..., 2017), nurses have the largest number of $49 \%$ (296,876 people) of the total human health resources utilized in health care facilities. The largest number of nurses in Central Java is 33,773 people. According to Law No. 38 of 2004, nursing services are a form of professional service from an integral part of health services based on the science and tips of nursing to individuals, groups and communities in good health and ill health (Ministry of Health..., 2017).

Health services are provided constantly and continuously (24 hours) to patients every day, so that the nursing profession contributes greatly in determining the quality of care in hospitals (Murtianingrum, 2009). This service condition affects every effort in improving the quality of hospital service and accompanied by efforts to improve the quality of nursing service (Mulyono et al., 2013).

\footnotetext{
* Corresponding author

E-mail addresses: ratna.permai@gmail.com (Honorata Ratnawati Dwi Putranti)
} 
In performing their duties professionally, a nurse has high work demands and uses a shift system as the work hours. The shift system causes a high level of stress if it only prioritizes the duty of work. In this condition, a person may experience health problems, both physical and psychological disorders (Felstead et al., 2002). Due to this factor, the work-life balance and burnout discourse in the life of the nurse is widely known.

Work-life balance has become an important issue in the work environment. It is considered a key factor in determining employee satisfaction, loyalty, and productivity (Yadav, 2014). The research found that female workers in educational field are more satisfied compared with female workers in IT field. However, this research did not discuss further on how to cope with this situation. This research is supported by a research conducted by Tanushree (2013) which suggests that modern organization is implemented in an effort to retain the employees. The practice of work-life balance can be done to influence organizational performance, save costs, improve productivity and reduce turnover. If the practice of work-life balance is reduced, employee turnover intentions also decrease in which reducing the errors can endanger patients and environmental staffs (Avgar et al., 2011). Workplace that fosters kinship and mutual support is important for all organizations in creating healthy working conditions (Sharma et al., 2016).

The current nursing profession is synonymous with female workers who account for $71 \%$ of the total nurses in Indonesia; based on the Indonesian National Nurses Association in April 2017. It puts the role of the working women tradition to face multiple roles. It contributes to the conflict between work and the family that becomes an obstacle in their work. Traditional or domestic roles include the role of women as wives, mothers and household managers. Meanwhile, the role of transition includes the definition of women as workers, community members and human development. In the transitional role, women as laborers are also actively involved in economic activities (earning a living) and in various activities in accordance with the skills and educational background and the available employment (Sukesi, 1991).

Work conflicts perceived or experienced by female workers will cause burnout. Inconsistent research findings on burnout correlation with employee performance, as in Prasetyorini, Prawesti's (2012) research found that there is no burnout correlation with nurse performance in nursing care at Inpatient Installation of Kediri Baptist Hospital, as all nurses have a good and enough performance despite experiencing burnout. However, other research has shown that there is a significant direct influence between burnout and performance. This research found a significant direct influence between burnout and lecturer performance. It means that the higher burnout experienced by lecturers at Widyagama University Malang, it will lead to decreasing performance (Anggarani, Ficilia, 2014). Emotional fatigue in the burnout dimension has no direct effect on organizational commitment but teacher job satisfaction. Commonly, emotional fatigue directly affects the teacher's job satisfaction and will subsequently affect the organizational commitment (Wirajaya, Supartha, 2016). Research conducted at PT. Jasa Raharja (Persero) North Sulawesi Branch obtains the findings that burnout has negative effect but not significant to job satisfaction of employee of PT. Jasa Raharja (Persero) branch of North Sulawesi but work-life balance and burnout simultaneously have a significant effect on job satisfaction (Pangemanan et al., 2011). It opens up the possibility that there is an intermediary variable for a person experiencing burnout toward the desire to stay in the organization and the performance within the organization.

Human resources play an important role in an organization. They are the greatest resources and their uniqueness makes them a pillar for an organization because they are committed to making the organization competitive. Committed employees are expected to be responsible for improving performance and devoting their time to the organization. Organizational commitment is often described as a key factor in relationships between employees and organizations (Griffith, Kraneburg, 2013).

The problems that become the formulation of research problem in this topic are: how does work-life balance affect job satisfaction? How does burnout affect job satisfaction? How does worklife balance affect organizational commitment? How does burnout affect organizational commitment? How does work-life balance and burnout affect organizational commitment with job satisfaction as intervening variable? How to manage nurse's work-life balance and burnout? 


\section{Literature Review}

\subsection{Work Life Balance}

Hospital nurses are the dominant human resources involved in providing hospital services. According to the data (Ministry of Health..., 2017), nurses have the largest number of $49 \%$ (296,876 people) of the total human health resources utilized in health care facilities. The largest number of nurses in Central Java is 33,773 people. According to Law No. 38 of 2004, nursing services are a form of professional service from an integral part of health services based on the science and tips of nursing to individuals, groups and communities in good health and ill health (Ministry of Health..., 2017).

The term of work-life balance was first recognized by the British people in the late 1970s. Work-life balance at that time was defined as a balance between individual work and individual personal life. However, within a few years after the term is known, work-life balance is still rarely mentioned and discussed in everyday life.

The awareness of the importance of paying attention to work-life balances on employees has not been realized by the existing companies at that time. However, as time went on, the awareness began to increase. Before World War II, Kellog Company tried to make changes by changing the work system: namely from 3 shifts with each 8 working hours to 4 shifts with each 6 working hours. It had a significant effect on the positive increase in employee morale and efficiency levels (Lockwood, 2003).

People's awareness of work-life balance became stronger until Rosabeth Moss Kanter finally managed to bring the issue of work-life balance into an interesting topic to study, through her book "Work and Family in the United States: A Critical Review and Agenda for Research and Policy". In the 1980s, several developed and developing companies began to offer work programs that pay attention to work-life balance for its employees. Work programs that pay attention to work-life balances were first applied to help women employees who were already married and had children. However, currently, the application of work-life balance programs is not limited by gender. As awareness increases, both men and women are committed to families as they are committed to the company they work.

Nowadays, the issue of work-life balance is not just a trend in major countries in Europe as well as in the United States. The employees globally have realized the importance of work-life balance, so they want a more flexible type of work. Although they are workers, they can also pay attention to their personal lives in the family.

2.2. Burnout

Burnout is a term that refers to the syndrome that is a collection of individual responses to stress. Burnout is a prolonged response to the ongoing stress factors that occur in the workplace in which the outcome is a mixture of workers and their work (Papalia et al., 2007).

Weiten (2010) explained that burnout includes physical, mental, and emotional fatigue caused by work-related stress which is common in individuals who work in social services. Physical fatigue includes feeling power loss, feeling weak or chronic fatigue. Mental fatigue may arise with a high negative attitude to a person, work, and life. Emotional fatigue arises from feelings of helplessness, hopelessness, and feeling trapped in the work.

2.3. Job Satisfaction

Kinicki, Kreitner (2006) define job satisfaction as a response to the overall part of an individual's work. They mean that an individual can be satisfied in one aspect of his/her work, but not satisfied with other aspects. An individual, who has a high level of job satisfaction, will have a positive feeling to his/her work. Conversely, an individual, who has a low level of job satisfaction, will have a negative feeling to his/her work (Robbins, Judge, 2013). Job satisfaction is the emotional response of an individual to the part of his/her job, which is related to the physical or social conditions in his/her workplace. A person's job satisfaction also includes the psychological side of an individual, associated with certain expectations of the work he/she does. In fact, the measurement of the level of job satisfaction is one of the forms of attention to the existing human resources (employees).

2.4. Organizational Commitment

Organizational commitment is the loyalty of employees to an organization through the acceptance of goals, organizational values, willingness to try to be part of the organization, and the desire to survive in an organization. 
Organizational commitment involves individual attachment to his/her work (Spector, 2000). Organizational commitment is a variable that reflects the degree of relationship that an individual perceives to a particular job in an organization. Organizational commitment reflects the level of individual identification and involvement in work and the unwillingness to leave the job.

From the above explanation, it is clear that commitment is a part related to employee performance in relation to the work.

This research uses path analysis. In data analysis, the concept of analysis process is carried out by using the concept developed by Sarwono (2007). The causality relationship will be used in path analysis or intervening variable. Path analysis is a technique of statistical analysis developed from multiple regression analysis. This technique is known as cross analysis or path analysis. Mathematically, this analysis is nothing but multiple regression analysis of standardized data. Thus, statistical software capable of performing multiple regression analysis can also be used for path analysis. The main subjects of this analysis are the correlated variables. This analysis bases itself on the relationship model among variables that was determined before by the researchers.

\subsection{Hypotheses}

2.5.1. Work-Life Balance Affects Job Satisfaction

Work-life balance can be defined as a life balance of leisure time, family, religion and work in which the career and ambition of an individual should be equal and balanced with the aim of reducing the tension between employee work and employee life, especially female nurses. Hospitals will help female nurses balance their life and work by creating family friendly benefit programs that support nurse welfare so that the nurses do not sacrifice their responsibilities.

Job satisfaction perceived by female nurses can be influenced by the level of life balance including spare time, family, religion and work namely the career and ambition of a nurse. Low levels of conflict will lead to job satisfaction. Thus, it can be said that if the work-life balance of an individual is good, in this case the female nurse, then it will have a positive effect on the individual's job satisfaction.

Based on the above description, the first hypothesis can be proposed as follows:

H1: the effect of work-life balance toward job satisfaction

2.5.2. Burnout Affects Job Satisfaction

Burnout can be interpreted as physical, mental, and emotional fatigue caused by workrelated stress. It is common for individuals working in social services. Female nurses in hospitals with high workload tend to experience physical exhaustion, mental and emotional exhaustion.

Job satisfaction experienced by a female nurse can be affected by the level of stress. Thus, if an individual has a high burnout level then it can affect the individual's job satisfaction within his/her work.

Based on the above description, the second hypothesis can be proposed as follows:

$\mathrm{H} 2$ : the effect of burnout toward job satisfaction

2.5.3. Work-Life Balance Affects Organizational Commitment

Based on a research that has been conducted by Moedy (2013), work-life balance can be interpreted as satisfaction and good function in workplace and home with low level of conflict. With a low level of conflict, it will create a commitment to its work. So, it can be said that if the work-life balance of an individual is good, then it will have a positive effect on organizational commitment of the individual.

Based on the above description, the third hypothesis can be proposed as follows:

H3: the effect of work-life balance toward organizational commitment

2.5.4. Burnout Affects Organizational Commitment

Weiten (2010) explained that burnout includes physical, mental, and emotional fatigue caused by work-related stress which is common in individuals who work in social services.

Female nurses who experience physical, mental, and emotional fatigue due to work-related stress will have an effect on their individual commitment. So that burnout can affect the organizational commitment to the individual's work.

Based on the above description, the fourth hypothesis can be proposed as follows:

$\mathrm{H} 4$ : the effect of burnout toward organizational commitment

2.5.5. Work-Life Balance and Burnout Affect Organizational Commitment with Job Satisfaction as Intervening Variable 
Robbins, Judge (2013) stated that an individual who has a high level of job satisfaction will have a positive feeling toward his/her work. Conversely, an individual who has a low level of job satisfaction will have a negative feeling toward his/her work. It may affect the individual's commitment to his/her work.

Organizational commitment can be interpreted as employee loyalty, especially in this research is female nurse, to organization or workplace (hospital) through the acceptance of goals, values, willingness to try to be part of hospital where they work and stay in the hospital.

If an individual has high job satisfaction, it will certainly affect the organizational commitment of the individual.

Based on the above description, the fifth hypothesis can be proposed as follows:

$\mathrm{H}_{5}$ : the effect of job satisfaction toward organizational commitment

\section{Research Method}

This research uses quantitative approach by distributing closed questionnaires, open questionnaires and interviews on female nurse nurses in dr. R. Soeprapto Hospital Cepu. The aim of distributing closed questionnaires is to obtain the results of hypothesis testing while the open questionnaire distribution is to better understand the process of work-life balance and burnout management on female nurses which cannot be answered only by using closed questionnaires.

3.1. Respondents

The population of this research is the female nurses as many as 113 people who work in dr. R. Soeprapto Hospital Cepu. The data collection of questionnaires and interviews was conducted at the end of January 2017 until March 2017. The population was used as a whole as research respondents.

3.2. Description of Respondents

Based on age, most respondents are aged 30-35 years as many as 35 people. It shows that the female nurses are in a productive age. Based on education, most respondents graduated from bachelor's degree and associate's degree as many as 67 people. It indicates that a nurse is required to have a high professional level with educational background in accordance with professional provisions. Based on marital status, most respondents have married status as many as 73 people. It illustrates that a nurse must perform a dual role (family and work).

3.3. Validity Test

Based on the validity test, it indicates that all variables are valid because the r-count of all research instruments has a value above 0.185 .

Table 1. The Results of Validity Test

\begin{tabular}{|c|c|c|c|c|}
\hline No & Variables/ Items & r-count & $\begin{array}{c}\text { r-table } \\
(\mathrm{p}=113)\end{array}$ & Description \\
\hline \multirow[t]{5}{*}{1.} & \multicolumn{4}{|l|}{ Work-Life Balance (X1) } \\
\hline & $\begin{array}{l}\text { It would be more convenient if the work at } \\
\text { the hospital can be completed on time } \\
\text { without having overtime }\end{array}$ & 0.344 & 0.185 & Valid \\
\hline & $\begin{array}{l}\text { It would be relieved and satisfied if able to } \\
\text { complete the job well without any obstacles }\end{array}$ & 0.524 & 0.185 & Valid \\
\hline & $\begin{array}{l}\text { It is easy to organize various roles as nurses, } \\
\text { wives and social roles in the society }\end{array}$ & 0.604 & 0.185 & Valid \\
\hline & $\begin{array}{l}\text { After work, there is still time for family, } \\
\text { relaxation and hobby }\end{array}$ & 0.675 & 0.185 & Valid \\
\hline \multirow[t]{5}{*}{2.} & \multicolumn{4}{|l|}{ Burnout (X2) } \\
\hline & Exhausted after work & 0.521 & 0.185 & Valid \\
\hline & Feel bored in carrying out the job & 0.554 & 0.185 & Valid \\
\hline & $\begin{array}{l}\text { It was difficult to gain valuable experience } \\
\text { during work }\end{array}$ & 0.630 & 0.185 & Valid \\
\hline & $\begin{array}{l}\text { Feeling agitated and irritable when } \\
\text { remembering about the job }\end{array}$ & 0.615 & 0.185 & Valid \\
\hline
\end{tabular}




\begin{tabular}{|c|c|c|c|c|}
\hline \multirow[t]{6}{*}{3 . } & \multicolumn{4}{|l|}{ Job Satisfaction (Intervening Variable) } \\
\hline & $\begin{array}{l}\text { Get the appropriate work wage with the level } \\
\text { of qualification, ability and expertise }\end{array}$ & 0.368 & 0.185 & Valid \\
\hline & $\begin{array}{l}\text { Co-workers are very cooperative (working } \\
\text { together) in work }\end{array}$ & 0.490 & 0.185 & Valid \\
\hline & $\begin{array}{l}\text { The workplace is comfortable so it supports } \\
\text { the job }\end{array}$ & 0.439 & 0.185 & Valid \\
\hline & The workplace hospital policy is flexible & 0.425 & 0.185 & Valid \\
\hline & $\begin{array}{l}\text { Being motivated to learn more with clear } \\
\text { career opportunities }\end{array}$ & 0.412 & 0.185 & Valid \\
\hline \multirow[t]{3}{*}{4.} & \multicolumn{4}{|l|}{ Organizational Commitment (Y) } \\
\hline & $\begin{array}{l}\text { Currently, staying in this organization is both } \\
\text { a necessity and a desire }\end{array}$ & 0.606 & 0.185 & Valid \\
\hline & $\begin{array}{l}\text { Having a strong sense of belonging to this } \\
\text { organization }\end{array}$ & 0.606 & 0.185 & Valid \\
\hline
\end{tabular}

Table 2. The Results of Reliability Test

\begin{tabular}{|l|l|c|c|c|}
\hline No & \multicolumn{1}{|c|}{ Variables } & $\begin{array}{c}\text { Cronbach's } \\
\text { Alpha }\end{array}$ & $\begin{array}{c}\text { Sig. a 60\% } \\
\text { (o.6) }\end{array}$ & Description \\
\hline 1. & Work-life balance & 0.731 & 0.06 & Reliable \\
\hline 2. & Burnout & 0.774 & 0.06 & Reliable \\
\hline 3. & Job satisfaction & 0.667 & 0.06 & Reliable \\
\hline 4. & Organizational Commitment & 0.739 & 0.06 & Reliable \\
\hline
\end{tabular}

Based on all the above reliable results, with sig. $\alpha 60 \%(0.6)$, then it can be stated that all instruments used are reliable.

\section{Findings and Discussions}

4.1. Classic Assumptions

4.1.1. Normality Test

Dependent Variable: Organizational Commitment

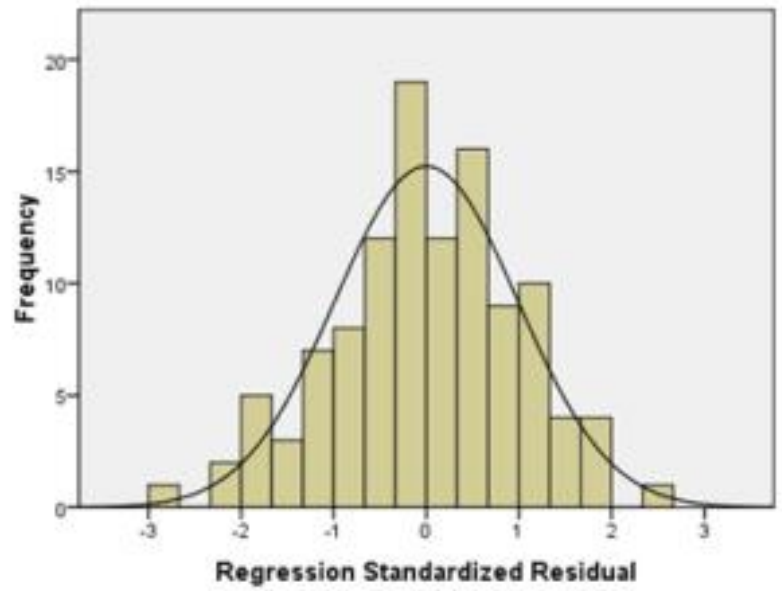

Fig. 1. Regression of Organizational Commitment 
Table 3. Multicollinearity Test Results

\begin{tabular}{|c|c|c|c|c|c|c|c|c|}
\hline \multicolumn{9}{|c|}{ Coefficients $^{\mathrm{a}}$} \\
\hline \multirow{2}{*}{\multicolumn{2}{|c|}{ Model }} & \multicolumn{2}{|c|}{$\begin{array}{l}\text { Unstandardized } \\
\text { Coefficients }\end{array}$} & \multirow{2}{*}{$\begin{array}{c}\begin{array}{c}\text { Standardized } \\
\text { Coefficients }\end{array} \\
\text { Beta }\end{array}$} & \multirow{2}{*}{$\mathrm{t}$} & \multirow{2}{*}{ Sig. } & \multicolumn{2}{|c|}{$\begin{array}{l}\text { Collinearity } \\
\text { Statistics }\end{array}$} \\
\hline & & B & $\begin{array}{c}\text { Std. } \\
\text { Error }\end{array}$ & & & & Tolerance & VIF \\
\hline \multirow[t]{4}{*}{1} & (Constant) & 8.527 & 1.281 & & 6.655 & .000 & & \\
\hline & Work-Life Balance & .106 & .045 & .188 & 2.362 & .020 & .801 & 1.248 \\
\hline & Burnout & -.278 & .039 & -.556 & -7.156 & .000 & .839 & 1.191 \\
\hline & Job Satisfaction & .043 & .052 & .068 & .823 & .413 & .749 & 1.335 \\
\hline & $\begin{array}{l}\text { endent Variable: } \\
\text { izational Commitn }\end{array}$ & & & & & & & \\
\hline
\end{tabular}

Table 3 shows that between the independent variables there is no multicollinearity problem in which the Variance Inflation Factor (VIF) test results indicate a value less than 10 (VIF <10).

4.1.2. Heteroscedasticity Test

Seatterplot

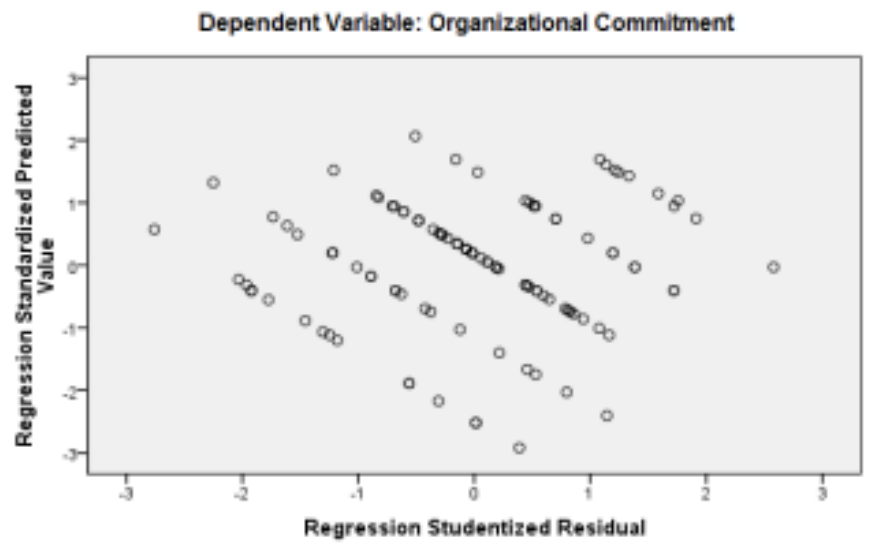

Fig. 2. Scatterplot of Organizational Commitment

From Figure 2, it can be seen that the data distribution appears irregular and does not form a specific pattern. It can be seen in the dispersed plots above and below the number $\mathrm{o}$ on the $\mathrm{Y}$ axis. Thus, it can be concluded that there is no heteroscedasticity problem in this regression model. In other words, this regression equation can satisfy the assumption of heteroscedasticity.

4.2. The Effect between Work-Life Balance and Job Satisfaction Variables

Table 4. The Effect between Work-Life Balance and Job Satisfaction Variables

\begin{tabular}{|c|c|c|c|c|c|c|}
\hline \multicolumn{7}{|c|}{ Coefficients $^{\mathrm{a}}$} \\
\hline \multirow{2}{*}{\multicolumn{2}{|c|}{ Model }} & \multicolumn{2}{|c|}{$\begin{array}{l}\text { Unstandardized } \\
\text { Coefficients }\end{array}$} & \multirow{2}{*}{\begin{tabular}{|l} 
Standardized \\
Coefficients \\
Beta
\end{tabular}} & \multirow[b]{2}{*}{$\mathrm{T}$} & \multirow[b]{2}{*}{ Sig. } \\
\hline & & $\mathrm{B}$ & Std. Error & & & \\
\hline 1 & (Constant) & 13.364 & 1.272 & & 10.507 & .000 \\
\hline & Work-Life Balance & .376 & .076 & .424 & 4.939 & .000 \\
\hline
\end{tabular}




\begin{tabular}{|c|c|c|c|c|c|c|}
\hline \multicolumn{7}{|c|}{ Coefficients ${ }^{\mathrm{a}}$} \\
\hline & & \multicolumn{2}{|c|}{$\begin{array}{l}\text { Unstandardized } \\
\text { Coefficients }\end{array}$} & \multirow{2}{*}{\begin{tabular}{|l} 
Standardized \\
Coefficients \\
Beta \\
\end{tabular}} & \multirow[b]{2}{*}{$\mathrm{T}$} & \multirow[b]{2}{*}{ Sig. } \\
\hline \multicolumn{2}{|c|}{ Model } & $\mathrm{B}$ & Std. Error & & & \\
\hline \multirow[t]{2}{*}{1} & (Constant) & 13.364 & 1.272 & & 10.507 & .000 \\
\hline & Work-Life Balance & .376 & .076 & .424 & 4.939 & .000 \\
\hline & ndent Variable: Job & Satisfac & & & & \\
\hline
\end{tabular}

The perception of work-life balance, from the perception of the respondents obtained through the questionnaire, shows that work-life balance is in good category. Based on the formulation of the research problems that have been described previously, from the results of hypothesis testing by t-test, it was found that there is a positive and significant effect between work-life balance and job satisfaction variables of nurses working in dr. R. Soeprapto Hospital Cepu. It means that the hypothesis proposed by the authors is accepted in which there is a positive and significant effect between work-life balance and job satisfaction variables of nurses working in dr. R. Soeprapto Hospital Cepu.

Work-life balance can be defined as a life balance of leisure time, family, religion and work in which the career and ambition of an individual should be equally balanced to reduce the tension between employee work and employee life, especially female nurses. Hospitals will help female nurses balance their life and work by creating family friendly benefit programs that support nurse welfare so that the nurses do not sacrifice their responsibilities. So, if the life balance of nurses working in dr. R. Soeprapto Cepu well preserved, then it will have effect and affect job satisfaction perceived by the nurses.

4.3. The Effect of Burnout and Job Satisfaction Variables

Table 5. The Effect of Burnout and Job Satisfaction Variables

\begin{tabular}{|c|c|c|c|c|c|c|}
\hline \multicolumn{7}{|c|}{ Coefficients $^{\mathrm{a}}$} \\
\hline & & \multicolumn{2}{|c|}{ Unstandardized Coefficients } & \multirow{2}{*}{\begin{tabular}{|l|}
$\begin{array}{l}\text { Standardized } \\
\text { Coefficients }\end{array}$ \\
Beta \\
\end{tabular}} & \multirow[b]{2}{*}{$\mathrm{t}$} & \multirow[b]{2}{*}{ Sig. } \\
\hline \multicolumn{2}{|c|}{ Model } & $\mathrm{B}$ & Std. Error & & & \\
\hline \multirow[t]{2}{*}{1} & (Constant) & 23.065 & .825 & & 27.947 & .000 \\
\hline & Burnout & -.296 & .069 & -.376 & -4.271 & .000 \\
\hline & endent Vari & e: Job Sa & & & & \\
\hline
\end{tabular}

Based on the formulation of the research problems that have been described previously, from the results of hypothesis testing by t-test, it was found that there is a negative and significant effect between burnout and job satisfaction variables of nurses working in dr. R. Soeprapto Hospital Cepu. It means that the hypothesis proposed by the authors is accepted in which there is a negative and significant effect between burnout and job satisfaction variables of nurses working in dr. R. Soeprapto Hospital Cepu.

Burnout can be interpreted as physical, mental, and emotional fatigue caused by workrelated stress. It is common for individuals working in social services. Female nurses in hospitals with high workload tend to experience physical exhaustion, mental and emotional exhaustion. So, if the level of physical, mental, and emotion fatigues caused by stress associated with the work of nurses working in dr. R. Soeprapto Hospital Cepu is high, then, it will have an effect and influence negatively on job satisfaction perceived by the nurses.

4.4. The Effect between Work-Life Balance and Organizational Commitment Variables 
Table 6. The Effect between Work-Life Balance and Organizational Commitment Variables

\begin{tabular}{|c|c|c|c|c|c|c|}
\hline \multicolumn{7}{|c|}{ Coefficients $^{\mathrm{a}}$} \\
\hline & & \multicolumn{2}{|c|}{ Unstandardized Coefficients } & \multirow{2}{*}{\begin{tabular}{|l|} 
Standardized \\
Coefficients \\
Beta \\
\end{tabular}} & \multirow[b]{2}{*}{$\mathrm{t}$} & \multirow[b]{2}{*}{ Sig. } \\
\hline \multicolumn{2}{|c|}{ Model } & $\mathrm{B}$ & Std. Error & & & \\
\hline \multirow[t]{2}{*}{1} & (Constant) & 4.367 & .826 & & 5.284 & .000 \\
\hline & Work-Life Balance & .211 & .049 & .375 & 4.266 & .000 \\
\hline
\end{tabular}

Based on the formulation of the research problems that have been described previously, from the results of hypothesis testing by t-test, it was found that there is a positive and significant effect between work-life balance and job satisfaction variables of nurses working in dr. R. Soeprapto Hospital Cepu. It means that the hypothesis proposed by the authors is accepted in which there is a positive and significant effect between work-life balance and job satisfaction variables of nurses working in dr. R. Soeprapto Hospital Cepu.

Work-life balance can be defined as a life balance of leisure time, family, religion and work in which the career and ambition of an individual should be equally balanced to reduce the tension between employee work and employee life, especially female nurses. Hospitals will help female nurses balance their life and work by creating family friendly benefit programs that support nurse welfare so that the nurses do not sacrifice their responsibilities. So, if the life balance of nurses working in dr. R. Soeprapto Cepu well preserved, then it will have effect and affect job satisfaction perceived by the nurses. If the balance of life is achieved well, then the organizational commitment will be achieved as well.

4.5. The Effect between Burnout and Organizational Commitment Variables

Table 7. The Effect between Burnout and Organizational Commitment Variables

\begin{tabular}{|c|c|c|c|c|c|c|}
\hline \multicolumn{7}{|c|}{ Coefficients $^{\mathrm{a}}$} \\
\hline & & \multicolumn{2}{|c|}{ Unstandardized Coefficients } & \multirow{2}{*}{\begin{tabular}{|l} 
Standardized \\
Coefficients
\end{tabular}} & \multirow[b]{2}{*}{$\mathrm{t}$} & \multirow[b]{2}{*}{ Sig. } \\
\hline \multicolumn{2}{|c|}{ Model } & B & Std. Error & & & \\
\hline \multirow[t]{2}{*}{1} & (Constant) & 11.583 & .437 & & 26.528 & .000 \\
\hline & Burnout & -.318 & .037 & -.635 & -8.661 & .000 \\
\hline
\end{tabular}

Based on the formulation of the research problems that have been described previously, from the results of hypothesis testing by t-test, it was found that there is a negative and significant effect between burnout and job satisfaction variables of nurses working in dr. R. Soeprapto Hospital Cepu. It means that the hypothesis proposed by the authors is accepted in which there is a negative and significant effect between burnout and job satisfaction variables of nurses working in dr. R. Soeprapto Hospital Cepu.

So, if the stress level of the nurses who work in dr. R. Soeprapto Hospital Cepu can be lowered or minimized, then it will have an effect on the increased organizational commitment perceived by the nurses.

4.6.The Effect between Job Satisfaction and Organizational Commitment Variables 
Table 8. The Effect between Job Satisfaction and Organizational Commitment Variables

\begin{tabular}{|c|c|c|c|c|c|c|}
\hline \multicolumn{7}{|c|}{ Coefficients $^{\mathrm{a}}$} \\
\hline & & \multicolumn{2}{|c|}{ Unstandardized Coefficients } & \multirow{2}{*}{\begin{tabular}{|l|}
$\begin{array}{l}\text { Standardized } \\
\text { Coefficients }\end{array}$ \\
Beta \\
\end{tabular}} & \multirow[b]{2}{*}{$\mathrm{t}$} & \multirow[b]{2}{*}{ Sig. } \\
\hline \multicolumn{2}{|c|}{ Model } & $\mathrm{B}$ & Std. Error & & & \\
\hline \multirow[t]{2}{*}{1} & (Constant) & 3.435 & 1.108 & & 3.101 & .002 \\
\hline & Job satisfaction & .226 & .056 & .356 & 4.017 & .000 \\
\hline & ndent Variable: $\mathrm{C}$ & anizati & mmitment & & & \\
\hline
\end{tabular}

Based on the formulation of the research problems that have been described previously, from the results of hypothesis testing by t-test, it was found that there is a positive and significant effect between job satisfaction and organizational commitment variables of nurses working in dr. R. Soeprapto Hospital Cepu. It means that the hypothesis proposed by the authors is accepted in which there is a positive and significant effect between job satisfaction and organizational commitment variables of nurses working in dr. R. Soeprapto Hospital Cepu. So, if the satisfaction of nurses who work in dr. R. Soeprapto Hospital Cepu is well preserved, then it will be job satisfaction that has a positive effect on their organizational commitments.

\subsection{Direct and Indirect Effects}

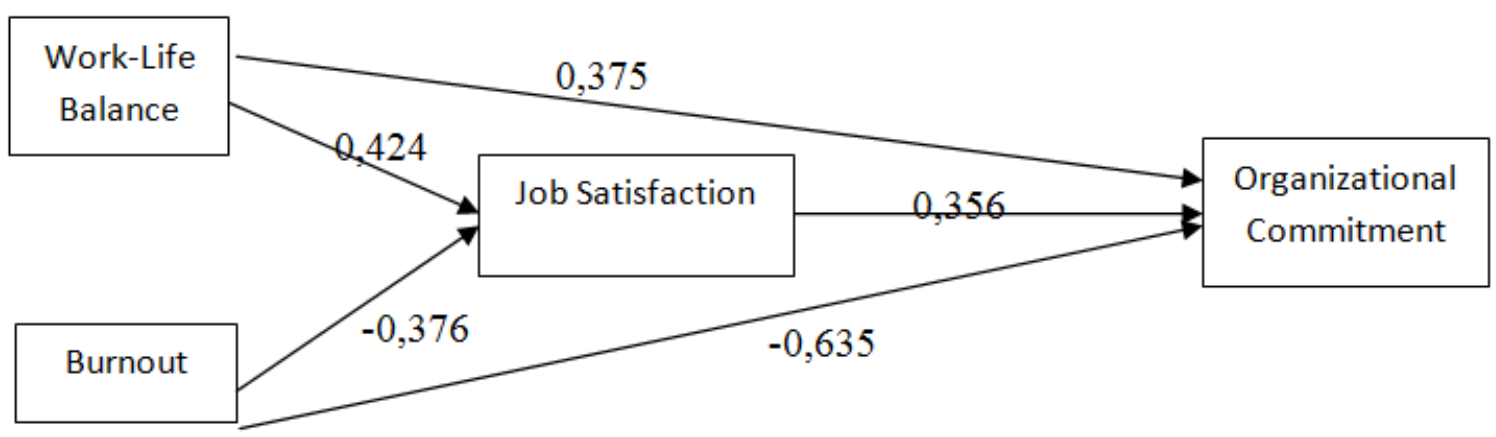

Fig. 3. Final Result of Research Model Coefficient

4.7.1. Direct and Indirect Effects between Work-Life Balance and Organizational Commitment Variables

Based on the figure above, it can be seen that the direct effect between work-life balance and organizational commitment variables is 0.375 . While indirect effect between work-life balance and organizational commitment variables through job satisfaction is equal to $=0.424 \times 0.356=0.151$.

Based on the above calculation, it is known that the value of direct effect is 0.375 and the indirect effect is 0.151 which means that the value of direct effect is greater than the indirect effect. Thus, it can be concluded that the direct effect of work-life balance toward organizational commitment variable is more significant.

4.7.2. Direct and Indirect Effects between Burnout on Organizational Commitment Variables

Based on the figure above, it can be seen that the direct effect between burnout and organizational commitment variables is equal to -0,635. While indirect effect between burnout and organizational commitment variables through job satisfaction is equal to $=-0.376 \times 0.356=-0.134$.

Based on the above calculation, it is known that the value of direct effect is -0.635 (negatively affected) and the indirect effect is -0.134 (negatively affected) which means that the value of direct effect is greater than the indirect effect although the effect is negative or opposite. Thus, it can be concluded that the direct effect of burnout on organizational commitment variable is more significant. 


\section{Discussion}

From in-depth interviews conducted to 113 female nurses, it was found out that the management of work life balance and burnout is divided into three main types: stimulus (reactive), preventive (responsive) and situational (common). It can be seen from the nurses' answers recapitulation in managing the situation at hand. The questions posed are: how do you (nurses) face a lot of work situation and are required to solve it? How to deal with stressful situations? Then, the results can be seen in Table 9.

Table 9. The Results of Interview

\begin{tabular}{|c|c|}
\hline Interview Result & Substances \\
\hline $\begin{array}{l}\text { Group } 1 \\
\text { 1. Having a lot of problems } \\
\text { 2. Experiencing stress that requires life balance } \\
\text { 3. Lazy to work } \\
\text { 4. During institutional accreditation } \\
\text { 5. Getting a problem at home } \\
\text { 6. Having many tasks }\end{array}$ & Stimulus / Reactive \\
\hline 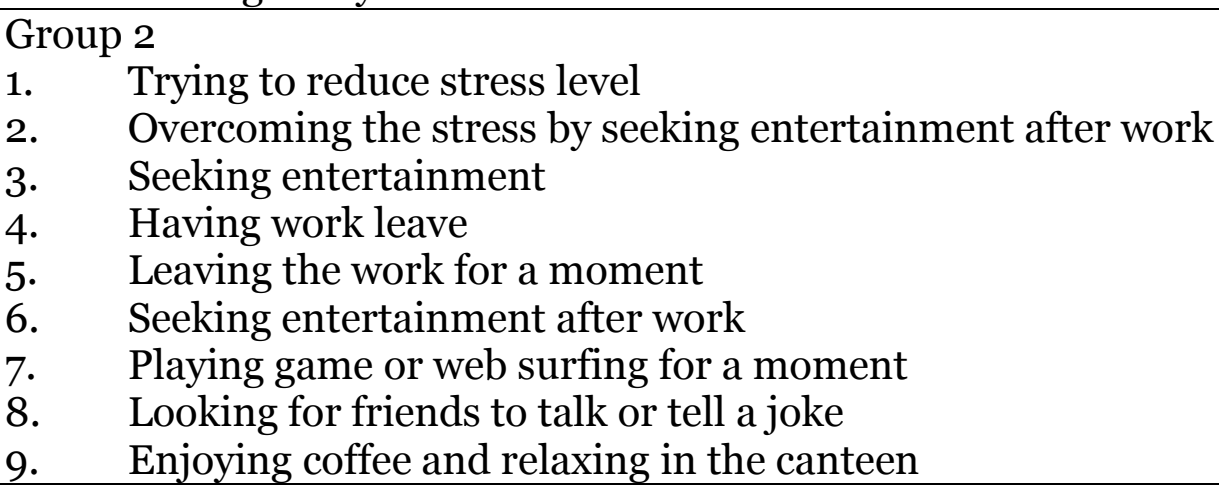 & $\begin{array}{l}\text { Preventive / } \\
\text { Responsive }\end{array}$ \\
\hline 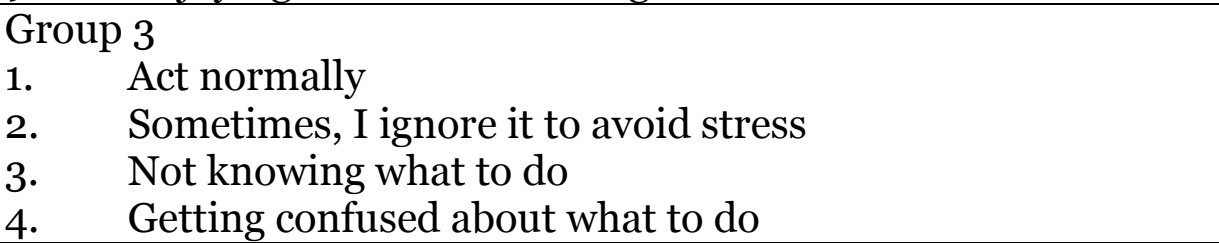 & $\begin{array}{c}\text { Transactional / } \\
\text { Common }\end{array}$ \\
\hline
\end{tabular}

An environment that makes a person very depressed can create stress (Bartlett, 1998). In addition, such individuals receive only direct stress stimuli without any assessment process (Staal, 2004). The causes of stress contribute to determining how much stress a person may receive. Therefore, pressure from situations in an environment can be a cause and a deterrent to health disorders if it occurs in frequent and dangerous times (Bartlett, 1998). Possible situations to be the trigger for stress are workload, heat, cold, noise, stinky room, too bright light, dirty environment, inadequate ventilation, etc. (Staal, 2004; Hariharan, Rath, 2008). When a person fails to deal with situations or changes that are extreme, then there are bad effects, such as the emergence of anxiety feeling (Lumban Gaol, 2016). Nurses might be triggered by stress when there is an event that depresses them at a certain time. For example, at the time of hospital accreditation, the nurse gets enough duties such as to serve the administration and keep doing patient duty. This condition can lead to a reaction to cope with stress (see Table 9). This condition occurs in the short term because if the work has been completed then it will return as before.

The results of stress are sourced from within the individual (Staal, 2004). The stress results include changes in psychological, emotional, and psychological conditions (Carr, Umberson, 2013). For example, when a person experiences an alarming situation, the body spontaneously reacts to the threat. Such threats include sources of stress and the body's response to the threat which is known as a stress response (Schneiderman et al., 2005). Thus, the combination of the source of stress and the result of stress leads to the notion that stress cannot be separated from the body's 
reaction. In other words, the body will not respond to anything without stimulation. When these conditions are experienced by the nurses, they anticipate it in various ways to cope with the stress they experience. Each individual has a different way of dealing with it (see Table 9).

The stress of the transactional model focuses on emotional responses and cognitive processes based on human interaction with the environment (Jovanovic et al., 2006). In other words, the stress of this model emphasizes the role of individual assessment of the causes of stress in which it will determine the individual's response (Staal, 2004). Some nurses feel that stress is a common thing or even feel that it is not a serious thing to be a problem. This condition is considered as a common thing or someone does not care and feel that they must avoid such situation (see Table 9). Stress is the result of the occurrence of transactions between individuals with stressors involving the evaluation process (Dewe et al., 2012). The source of stress is an event or situation that exceeds the ability of the mind or body when experiencing with the source of stress. When this situation occurs, the individual will do appraisal and coping. Therefore, stress may progress to a more severe stage or diminish gradually. It determines on how a person's efforts in dealing with the source of stress.

Job satisfaction is an emotional attitude of employees in loving their work (Hasibuan, 2008). Job satisfaction reflects the attitude of employees to their work. If the employees are positive about the work they are doing, they will get a feeling of satisfaction with what they are doing. Conversely, if employees behave negatively (dislike), then they will feel dissatisfied with what they will do. This situation will be very profitable, so the company can run the strategy and targets to be achieved. Kristianto et al. (2011) found that job satisfaction had a positive and significant effect on organizational commitment. Stress is one of the things that can trigger an employee's dissatisfaction. Based on the empirical results, the findings state that 21 nurses working in dr. R. Soeprapto Hospital Cepu obtained job satisfaction because of the appropriate salary, 13 people because of work facilities that were fulfilled, 8 because of pleasant friends, and 71 people did not answer. The highest number of 71 people did not answer because job satisfaction is a situational condition that depends on each individual.

Companies must be able to create job satisfaction for employees in order to maximize the service quality (Munhurrun et al., 2010). Job satisfaction can be viewed from two sides; from the side of the employee, job satisfaction will bring a feeling of pleasure in working, while from the side of the company, job satisfaction will increase productivity, attitude improvement, and employee behavior in providing excellent service (Suwatno, Priansa, 2011). Hammer, Avgar (2005) stated that employees will tend to leave the organization if they are not satisfied with the work climate and job characteristics. From the interview results, that asking whether or not the nurse wanted to leave work, 26 people answered never, 15 answered that they sometimes had a desire to leave, while 72 did not answer. Most unresponsive people considered that this condition was unimportant and there is a more driving and retaining factor in deciding whether they want to stay or leave the company. A research conducted by Putranti, Tiyoso (2017) found that there are retention factors from employees that affect the intensity of a person before deciding to leave the company.

\section{Conclusion}

Work-life balance has a positive and significant impact on job satisfaction. The life balance including leisure time, family, religion and work including career and ambition of an individual should be equally balanced because it is intended to reduce the tension between work and life of employees, especially female nurses. Hospitals will help female nurses to balance their lives and work by creating family friendly benefit programs that support nurse welfare so that the nurses do not have to sacrifice their responsibilities.

Burnout has a negative and significant effect on job satisfaction. High stress and burnout cause dissatisfaction in working. Based on empirical studies that have been conducted before, each individual has a different way to complete the stage of stress and burnout respectively. This is because each nurse has a different meaning in facing the stress.

Work-life balance has a positive and significant effect on organizational commitment. So, if the life balance of the nurses working in dr. R. Soeprapto Hospital Cepu is well preserved, it will have a positive effect and may affect the organizational commitment perceived by the nurses. If the life balance is achieved well then organizational commitment will be achieved as well. Burnout has a negative and significant effect on organizational commitment. The higher the stress that leads to burnout, it will cause the organizational commitment of the employee decreases and 
the desire to leave the company increases. However, stress at this particular stage generates stimulation to do so. This condition is highly dependent on each individual and the type of stress that is being experienced with various types of factors that trigger the stress.

\section{Limitation of the Research}

This research has not revealed the direct effects caused by the decreasing organizational commitment process and increasing organizational commitment caused by independent variables of work-life balance and burnout. Thus, further research is required to find out more data in the process of these effects that are accompanied by time and effect factors.

\section{References}

Anggraini, Ficilia, 2004 - Anggarani, D., Ficilia, I. (2014). Analisis Pengaruh Profitabilitas dan Risiko terhadap Modal Kerja Bersih pada Perusahaan Tekstil di Bursa Efek Indonesia. Jurnal Manajemen dan Akuntansi, 1(3), 104-116.

Avgar et al., 2004 - Avgar, A.C., Givans, R.K., Liu, M. (2011). A Balancing Act: Work-Life Balance and Multiple Stakeholder Outcomes in Hospitals. British Journal of Industrial Relations, 49(4), 717-741.

Bartlett, 1998 - Bartlett, D. (1998). Stress: Perspectives and Processes. Philadelphia, USA: Open University Press.

Carr, Umberson, 2013 - Carr, D., Umberson, D. (2013). The social psychology of stress, health, and coping. In DeLameter, J. Ward, A. (Eds.). Handbook of Social Psychology. Netherlands: Springer, pp. 465-487.

Dewe et al., 2012 - Dewe, P.J., O’Driscoll, M.P., Cooper, C.L. (2012). Theories of psychological stress at work. In Gatchel, R. J. \& I. Z. Schultz, I. Z. (eds.) Handbooks in health, work, and disability. USA: Springer, pp. 23-38.

Felstead et al., 2002 - Felstead, A., Jewson, N., Phizacklea, A., Walters, S. (2002). Opportunities to work at home in the context of work-life balance. Human Resource Management Journal, 12, 54-76.

Griffith, Kranenburg, 2013 - Griffith, D., Kranenburg (2013). The effect of organizational Culture and Leadership style on organizational commitment within SMES in suriname with job satisfaction as a Mediator.An article was submitted of FHR Lim A Po Institute for Social Studies in association with the Maastricht school of Management.

Hammer, Avgar, 2005 - Hammer, T.H., Avgar, A. (2005). The impact of union on job satisfaction, organizational commitment and turnover. Journal of Labour Research, 26(2), 241-266.

Hariharan, Rath, 2008 - Hariharan, M., Rath, R. (2008). Coping with life stress: The Indian experience. India: SAGE Publications India Pvt Ltd.

Hasibuan, 2008 - Hasibuan, Malayu S.P. (2008). Manajemen Sumber Daya Manusia. Jakarta: PT. Bumi Aksara.

Jovanovic et al., 2006 - Jovanovic, J., Lazaridis, K., Stefanovic, V. (2006). Theoretical approaches to problem of occupational stress. Acta Facultatis Medicae Naissensis, 23(3), 163-169.

Kinicki, Kreitner, 2006 - Kinicki, A., Kreitner, R. (2006). Perilaku Organisasi, Buku 1, Edisi Lima. Jakarta: Salemba Empat.

Kristianto et al., 2012 - Kristianto, D., Suharnomo, Ratnawati, I. (2012). Pengaruh Kepuasan Kerja terhadap Kinerja Karyawan dengan Komitmen Organisasional Sebagai Variabel Intervening. (Studi Pada RSUD Tugurejo Semarang). Jurnal Universitas Diponegoro.

Lockwood, 2003 - Lockwood, N.R. (2003). Work/Life Balances : Challenges And Solutions" Society For Human Resource Management. SHRM Research Journal.

Lumban Gaol, 2016 - Lumban Gaol, N.T. (2016). Teori Stres: Stimulus, Respons, dan

Transaksional. Buletin Psikologi, 24(1), 1.

Ministry of Health..., 2016 - Ministry of Health of the Republic of Indonesia. Situasi Tenaga Keperawatan Indonesia 2017.

Moedy, 2013 - Moedy, D.M.R. (2013). Analisis Work-Life Balance, Keinginan Untuk Meninggalkan Organisasi,Kepenatan (Burnout) Dan Kepuasan Kerja Pada Dosen Universitas Atma Jaya Yogyakarta. E-Journal: Universitas Atma Jaya Yogyakarta. 
Mulyono et al., 2013 - Mulyono, M.H., Hamzah, A., Zulkifli, A.A. (2013). Faktor yang Berpengaruh terhadap Kinerja Perawat di Rumah Sakit Tingkat III 16.06.01 Ambon. Jurnal AKK, 2(1), 18-26.

Munhurrun et al., 2010 - Munhurrun, P.T, Naido P., Bhiwajee, SDL. (2010). Measuring service quality: perceptions of employees. Journal of Business Research, 4(1), 47-58.

Murtiningrum, 2005 - Murtiningrum (2005). Analisis Pengaruh Konflik-Pekerjaan Keluarga Terhadap Sters Kerja Dengan Dukungan Sosial Sebagai Variable Moderasi.

Pangemanan et al., 2011 - Pangemanan, F.L., Pio, R.J., Tumbel, T.M. (2011). Pengaruh Work Life Balance dan Buronut terhadap Kepuasan Kerja, 1-8.

Papalia et al., 2007 - Papalia, D.E., Olds, S.W., Feldman, R.D. (2007). Human development (10th ed.). New York : McGraw Hill.

Prasetyorini, Prawesti, 2012 - Prasetyorini, H.T., Prawesti, D. (2012). Stres Pada Penyakit Terhadap Kejadian Komplikasi Hipertensi Pada Pasien Hipertensi. Jurnal Stikes, 5(2), 121-132.

Putranti, Tiyoso, 2017 - Putranti H.R.D., Tiyoso J.S.P. (2017). Diagnosis Of Middle Manager's Individual Working Behavior In Turnover Intention Transition Phase. RJOAS, 6(June), 205-214.

Robbins, Judge, 2013 - Robbins, S. P., Judge, T. A. (2013). Organizational Behavior Edition 15. New Jersey: Pearson Education.

Schneiderman et al., 2004 - Schneiderman, N., Ironson, G., Siegel, S.D. (2004). Stress and health: Psycho- logical, behavioral, and biological determinants. Annual review of clinical psychology, 1, 607-628.

Sharma et al., 2016 - Sharma, S., Parmar, J.A.I.S., Chauhan, S.S. (2016). Work-related Variables and Work - Life Balance - A Study of Nurses in Government Hospitals of Himachal Pradesh. Productivity, 57(3), 286-292.

Spector, 2000 - Spector, P.E. (2000). Industrial and Organizational Psychology Research and Practice (second edition). New York: John Wiley \& Sons, Inc.

Staal, 2004 - Staal, M.A. (2004). Stress, cognition, and human performance: A literature review and conceptual framework. Nasa technical memorandum, 212824, 9. [Electronic resource]. URL: http:// humanfactors.arc.nasa.gov/web/library/ publications/publications.php

Sukesi, 1991 - Sukesi, K. (1991). Status dan Peranan Perempuan: Apa Implikasinya Bagi

Studi Perempuan. Warta Studi Perempuan. Vol. 2 No 1. Jakarta: PDII-LIPI.

Suwatno, Priansa, 2011 - Suwatno, H., Priansa, D.J. (2011). Manajemen SDM dalam

Organisasi Publik dan Bisnis. Bandung: Alfabeta.

Tanushree, 2013 - Tanushree (2013). Focusing on Employee Work Life Balance: A Study of Gas Authority of India Ltd. Global Journal of Commerce \& Management Perspective, 2(1), 47-49.

Weiten, 2010 - Weiten, W. (2010). Psychology: Themes and variations (8th ed.). California: Wadwort.

Wirajaya, Supartha, 2016 - Wirajaya, I.G.A., Supartha, I.W.G. (2016). Burnout Terhadap Komitmen Organisasional Guru Fakultas Ekonomi dan Bisnis Universitas Udayana (Unud ), Bali, Indonesia profession) yang penuh tantangan (Maslach \& Jackson, 1986, dalam Wardhani, 2012, Peran guru sangat penting dalam mentransformas, 5(8), 4779-4806.

Yadav, 2014 - Yadav, N. (2014). Comparison of the work life balance of women employees in educational field (degree colleges permanent employees) and IT industries. SIES Journal of Management, 10(1), 36-42. 